\title{
MODERN STRATEGY, NEW METHODS AND MEANS FOR CONTROL OF
} HELMINTHIASES IN UZBEKISTAN

A. O. ORIPOV ${ }^{1}$, Doctor of Veterinary Sciences, Professor

E-mail: uzniiv@mail.ru

N. E. YULDASHEV ${ }^{2}$, Doctor of Veterinary Sciences, Senior Research Fellow, State Scientific Center for the Circulation of Veterinary Medicines and Feed Additives E-mail: gnkc@ vetgov.uz

${ }^{1}$ Scientific Research Institute of Veterinary Medicine of the Republic of Uzbekistan, 35 A. Beruniy st., village Taylyak, Taylyak district, Samarkand region, Republic of Uzbekistan ${ }^{2}$ State Committee for Veterinary Medicine and Livestock Development of the Republic of Uzbekistan, 100 Didor st. Chilanzar district, Tashkent, Republic of Uzbekistan

\begin{abstract}
The modern strategy to control the main, widespread helminthiases of farm animals provides for a complex of anthelmintic measures, including planned therapeutic and preventive deworming based on data from the study of the epizootology of helminthiases in each specific climatic-geographical zone; the implementation of measures for the pasture prevention of geohelminthiases and the control of the main, intermediate, and additional hosts for causative agents of biohelminthiases, including zoonotic helminthiases (echinococcosis, cenurosis, and cycticercoses); the implementation of measures for chemoprophylaxis of helminthiases in certain branches of animal husbandry, for example, in sheep breeding; by using anthelminticsalt mixtures; the use of agents that increase the immunobiological protective properties of the animal body against helminthiases and other diseases through the widespread use of vitamins, micro-and macroelements and other biological stimulants.
\end{abstract}

Keywords: helminths, helminthiases, deworming, molluscicides, anthelmintics, anthelmintic-salt mixtures, immunostimulants

\section{Introduction}

It is known that the control of animal helminthiases includes the following main measures: planned therapeutic and preventive deworming, the volume (multiplicity) and terms of which is based on the pathogen biology and epizootology of parasitic infections; prevention of animal infestation with pathogens of helminthiases based on the neutralization (disinfection) of the external environment in relation to geohelminthiases (soil-transmitted helminthiases) and the control of intermediate and additional hosts of pathogens of many biohelminthiases, as well as measures aimed at preventing infestation of productive animals with pathogens of larval cestodiases (echinococcosis, coenurosis, and cysticercosis); chemoprophylaxis and measures that increase the general immunobiological resistance of the animal body to helminthiases and other diseases.

\section{Analysis of recent research and publications}

Livestock productivity depends on many factors, such as animal feeding, keeping, and health. Among the animal health problems, parasitic diseases constitute a significant part. Livestock are parasitized by various helminth species, the most important being gastrointestinal nematodes, lungworms, and liver fluke. These pathogens can cause severe disease, affect productivity in all classes of stock, and are amongst the most important production-limiting diseases of grazing ruminants. Essentially all herds/flocks in a grass-based production system are affected. Infections with gastrointestinal nematodes and liver fluke are more chronic and the major economic impact is due to sub-clinical infections causing reduced growth, milk yield, and fertility. Infections with lungworm are more acute and can place a sudden high economic burden on a farm due to mortalities and sharp decreases in milk yield (Charlier et al., 2015).

The economic burden of helminthiases for the livestock industry is quite high. For example, in 2020, Charlier et al. conducted an assessment of the economic burden of 3 major parasitic helminth infections (gastrointestinal nematodes, Fasciola hepatica, and Dictyocaulus viviparus) to the ruminant livestock industry in Europe. The economic impact of these parasitic helminth infections was estimated by a deterministic spreadsheet model as a function of the proportion of the ruminant population exposed to grazing, the infection frequency and intensity, the effect of the infection on animal productivity and mortality and anthelmintic treatment costs. Also, they estimated the costs of anthelmintic resistant nematode infections and collected information on public research budgets addressing helminth infections in ruminant livestock. According to their data, the combined annual cost of the three helminth infections in 18 participating countries was estimated at $€ 1.8$ billion. Eighty-one percent of this cost was due to lost production and $19 \%$ was attributed to treatment 
costs. The cost of gastrointestinal nematode infections with resistance against macrocyclic lactones was estimated to be $€ 38$ million annually. The annual estimated costs of helminth infections per sector were $€ 941$ million in dairy cattle, $€ 423$ million in beef cattle, $€ 151$ million in dairy sheep, $€ 206$ million in meat sheep and $€ 86$ million in dairy goats (Charlier et al., 2020).

The impact of the helminth infections could be understood from the fact that treatment of lactating animals with anthelmintic drugs resulted in an increase of $4-18 \%$ in milk production. The liver flukes and amphistome parasites are responsible for decreased productivity through stunted growth, reduced fertility, and diminishing the quality as well as quantity of milk and meat. The amphistomes along with gastrointestinal nematodes could be responsible for a significant reduction (approximately $0.4-3.0 \mathrm{~L} /$ day) in milk production in cows. The production losses are not the sole source of economic losses rather the cost of treatment also contributes a major chunk to the overall losses incurred to the global livestock industry (Rehman \& Abidi, 2021).

The treatment and prevention of helminthiases in farm animals is not only important for the productivity of animal husbandry but also have a crucial value for human health. It is well known that several helminth infections are common for both animals and human. Helminth zoonoses are parasitic infections that can be shared by animals and humans (Arias et al., 2013). Various parasites infecting humans depend on vertebrate animals to complete their life cycle. Humans most commonly become infected with these zoonotic parasites through the consumption of infected hosts or through fecal-oral contamination. The results of these infections may vary from asymptomatic carriership to long-term morbidity and even death. Although data are still scarce, it is clear that these parasitic zoonoses present a significant burden for public health. Moreover, parasitic zoonoses can lead to significant economic losses, both directly, through their adverse effects on human and animal health, and indirectly, through control measures required in the food production chain (Devleesschauwer et al., 2014).

Nowadays, one of the most prevalent zoonotic diseases is infection with helminth parasites, which infect about one-third of the human population worldwide (Reda, 2018). Such widespread epidemiology of these infections can be attributed to a range of human factors including social and dietary changes as well as increased mobility of the human population. As human population grows, the demand for ffood products with a high protein content increases under intensive farming, which is inevitably leading to a greater spread of animal diseases and their transmission to humans. Some of the most important and well-known human zoonoses are caused by worm or helminth parasites, including species of nematodes (trichinellosis), cestodes (cysticercosis, echinococcosis), and trematodes (schistosomiasis) (Robinson \& Dalton, 2009).

The extraordinary prevalence of helminth infections undoubtedly reflects their ability to manipulate the host immune system, suppressing responses that could result in their ejection. Host immunity has also developed (over eons of coevolution with parasites) mechanisms to limit pathology and to best balance susceptibility, resistance, and immune pathogenesis. Hence, immune responses often permit ongoing infection in preference to complete parasite elimination and the collateral damage that would result. In other cases, this balance is upset, and immune dysregulation and pathology ensue (McSorley \& Maizels, 2012).

Many of the parasitic worms have complex multistage life cycles that involve several hosts. Within their mammalian hosts, they often undergo extensive growth and differentiation with the ultimate goal of producing stages intended for transmission to the next intermediate host. Usually, the life stage responsible for infecting the mammalian host is the larva, and the larva must migrate within the host to its appropriate niche where it can grow and reproduce. Since the offspring are intended for transmission to another animal, they must necessarily be capable in some way of entering a site from which they can leave the host. How all this is accomplished varies from one helminth to another. Nevertheless, despite this extensive organismal complexity, in the majority of cases the immune responses of the hosts to worm infection are remarkably similar (MacDonald et al., 2002).

Whenever parasitic worms such as platyhelminths (flatworms) and nematodes (roundworms) invade their host, there is a need for hemostasis and outwitting host immune defenses and expulsion mechanisms. The helminth produces excretory-secretory antigens which mediate a protein-protein interaction in the extracellular ambiance with either the fluid phase or host receptor cells. Excretory-secretory antigen production is not to overtake the immune system but to modulate and manipulate the immunity of the host to their own favor. The autonomous immune system of the host, on the other hand, respond to the invasion of the parasite by inducing the production and mobilization of certain proteins such as; cytokines (interleukin-13, interleukin-10, interleukin-5, and interleukin-4), non-specific immunoglobulin E, parasite-specific immunoglobulin, mobilization of mast cells, basophils and eosinophils. These collections of responses to helminths are known as the T-helper-2 (Th2) immune response (Idris et al., 2019). 
In many chronic helminth infections, however, the protective type 2 response appears to be restrained by the body's own immunosuppressive mechanisms, such as regulatory $\mathrm{T}$ cells and the down-modulatory cytokines they produce, which results in ineffective and unresponsive immune cell populations that cannot eliminate the parasite. The ability of helminth parasites to promote host regulatory pathways to block Th2 immunity is equally apparent in human and animal infections, presenting in both settings a shared challenge of directing new vaccines to select protective and not counter-productive components of the immune system. One consequence of the immunoregulatory nature of helminth parasites is that most individuals fail to develop protective immunity to infection, despite frequent exposure to infective stage parasites. Even following curative drug treatment, subjects show little resistance to rapid reinfection with soil-transmitted nematodes that establish in the intestinal tract (Hewitson \& Maizels, 2014).

Despite significant advances in parasite immunology research, challenges remain in understanding how precisely helminths interact with their hosts and tolerate the complex immune responses generated against them, and how to use such knowledge to develop new ways of combating these parasitic infections (Foster \& Elsheikha, 2012).

Control of helminth parasites is a key challenge for human and veterinary medicine. Although there are many different approaches to the control of helminth parasitism in livestock, including nutritional, immunological, and biological interventions, at present, effective control relies almost exclusively on effective synthetic anthelmintic drugs (Tsotetsi et al., 2013; Kotze et al., 2020; Nixon et al., 2020). Most of these compounds have broad-spectrum activity, but effective control ultimately relies on multiple treatments each year (Morgan et al., 2013). In some cases, organic farming, for instance, plant-derived or homeopathic preparations are preferred to synthetic drugs. Commercial plant preparations only show an anthelmintic activity in only a very few cases, and up to now, they have not proven their efficacy. Homeopathic drugs are not claimed as having an anthelmintic efficacy but rather promote the resilience of hosts to infections (Cabaret et al., 2002).

Anthelmintics were primarily generated for the treatment of veterinary parasites, and their application has then been expanded for the treatment of human patients. They have a variety of chemical entities and act through several modes of action (Alavi \& Shahmabadi, 2021). The mode of action of most anthelmintic drugs depends on the affinity of the parasite's signal protein, anion and cation channels and neuromuscular receptors to the drug. The drug binds to these sites and causes instability, spastic paralysis, or the death of the parasite (Idris et al., 2019).

According to chemical structures and pharmacological properties, there are seven classes of modern anthelmintics, including benzimidazoles, probenzimidazoles, tetrahydropyrimidines, imidazothiazoles, isoquinolines, salicylanilides, and macrocyclic lactones. The pharmacokinetics of anthelmintics, including their absorption, distribution, and biotransformation/elimination pattern, are critical factors, which determine the time to a maximum effect-site concentration of the drugs in the body. Anthelmintics are administered by oral drench (as a general route), slow-release bolus, injection, or in-feed. Drug entrance and accumulation into a parasitic worm are crucial factors to achieve the optimal therapeutic outcome. Also, other factors, such as i) the balance among drug entry, ii) the capacity of the parasite to metabolize and inactivate the drug, and iii) the drug efflux capacity of the parasite, determine the drug accumulation within a parasite. The exposure time of parasite to active drug concentrations is a critical factor that affects the efficacy and/ or durability of activity of most anthelmintics used in ruminants. Overall, these factors are responsible to determine the ultimate anthelmintic activity (Alavi \& Shahmabadi, 2021).

Despite the extraordinary success in the development of anthelmintics in the latter part of the last century, helminth parasites of domestic ruminants continue to pose the greatest infectious disease problem in grazing livestock systems worldwide. Newly emerged threats to continuing successful livestock production, particularly with small ruminants, are the failure of this chemotherapeutic arsenal due to the widespread development of anthelmintic resistance at a time when the likelihood of new products becoming commercially available seems more remote. In the context of helminth control in ruminant livestock, the mindset of 'suppression' needs to be replaced by 'management' of parasites to maintain long-term profitable livestock production. Existing effective chemical groups need to be carefully husbanded and non-chemotherapeutic methods of parasite control need to be further researched and adopted, if and when, they become commercially available (Waller, 2006).

When first introduced, all anthelmintic drugs are highly efficacious, but frequent and widespread use and misuse has resulted in the emergence of resistant parasite populations, such that anthelmintic resistance is now a major global problem and is the greatest threat to the sustainable control of helminthiases in the short to medium term (Morgan et al., 2013). The impact of this has been particularly severe in the livestock industries, with significant levels of resistance worldwide in gastrointestinal nematodes of sheep, goats, and 
cattle. Resistance to anthelmintics is also widespread in gastrointestinal parasites of horses and canines. Minimizing the impact of drug resistance requires an ability to detect its presence. This allows for drug-use decisions to be made based on the knowledge of what drugs remain effective against the target helminth population. Once resistance has been detected to a particular drug or drug class, the use of alternative drugs ensures that parasitic infections can be effectively controlled and that further selection pressure is not applied by the drug for which resistance is emerging (Kotze et al., 2020).

Risk factors for anthelmintic resistance development include parasite biology and epidemiology, the dynamics of the host-parasite relationship, treatment frequency, treatment strategies that result in various levels of refugia and differences in anthelmintic pharmacokinetics between host species. Preserving "refugia" (the proportion of populations of parasites not exposed to anthelmintics) is the current goal of parasite control in small ruminants and horses and has been deemed the single most important factor involved in the selection of anthelmintic resistance parasites. A selective approach to deworming is currently recommended in veterinary medicine in order to preserve refugia and slow anthelmintic resistance. Animals in the herd that are the least clinically affected based on fecal egg counts are left untreated. Anthelmintics are then administered to the most affected when there are more eggs and larvae on the pasture so the presence of susceptible parasite populations on pasture will "dilute" the resistant populations and thereby preserve refugia (Tinkler, 2020).

The eradication of helminth infections remains a distant goal, due to a lack of effective vaccines, limited pharmacological efficacy, emerging drug resistance, and rapid reinfection in environments where the transmission cannot be interrupted (McSorley \& Maizels, 2012). This requires the development of alternative treatment approaches and drugs for the control of helminths (Reda, 2018; Idris et al., 2019).

The resistance of helminths to drugs over the years generated a hypothesis on whether preventive chemotherapy could be used against helminthiasis. Currently, the work on the development of prophylactic vaccines (as an alternative to anthelmintics) is carried out and there are some successful attempts. For livestock, a subunit vaccine called Barbervax, developed in Australia, has been commercialized for Haemonchus contortus that consists of a complex combination of native antigens from the worm's gut. Barbervax is about $70 \%$ effective at reducing worm burdens and about $90 \%$ effective at reducing the number of eggs in the feces, which greatly reduces egg numbers throughout the pasture, and thus, the number of infections later on (Noon \& Aroian, 2017). The vaccines for trichuriasis and ascariasis are currently undergoing preclinical testing. Hookworm, schistosomiasis, onchocerciasis and other soil-transmitted helminthiases vaccines are in various stages of development (Idris et al, 2019). However, the development of vaccines against parasitic infections often is quite complicated due to challenges in their manufacturing, preclinical and clinical research.

The control of helminthiases in farm animals is a global challenge considering the high prevalence of helminth infections and significant economic losses from these diseases. In every country all over the world, there is a distinct peculiarity in strategy to control and prevent helminthiases in farm animals according to social, economic, geographic and other factors. This determines the purpose of our work - to study the modern strategy, new methods and means for control of helminthiases in the Republic of Uzbekistan.

\section{Materials and methods of researches}

A systematic review of literature sources concerning methods and tools for control of helminthiases was conducted. The methods of analysis and synthesis of scientific data were used. According to the main tasks of the article, the relevant scientific papers from the Republic of Uzbekistan were selected for review.

\section{Results of the research and their discussion}

Means and methods of planned deworming, in particular, anthelmintic drugs and methods of their application, as well as their effectiveness against different groups of helminthiases - trematodiases, cestodiases, and nematodoses are widely and comprehensively covered in fundamental works (Demidov \& Potemkina, 1980; Demidov, 1982). Several studies have been carried out to improve methods of deworming (Dolnikov, 1956; Oripov \& Petrosyan, 1974; Oripov, 1978; Oripov, 1978a; Oripov, 1980; Oripov, 1990) as well as searching for new anthelmintic drugs (Oripov et al., 2016 ; Oripov et al., 2016 ${ }^{\mathrm{b}}$; Oripov et al., 2020).

An important part in the complex of measures to control helminthiases, as is known, is the control of intermediate hosts of pathogens of biohelminthiases. In particular, control of freshwater snails of the family Lymnaeidae and Planorbidae has important and sometimes crucial value for the prevention of widespread dangerous trematodiases in farm animals, such as fasciolosis, schistosomiasis (orientobilharziasis), and paramphistomatosis (Mereminskii, 1967; Gorokhov, 1970; Zharikov, 1975; Yuldashev \& Oripov, 2016), while it is important to control oribatid mites - intermediate hosts of the pathogens of cestodiases for pasture prevention of anoplocephalatoses (monieziosis )(Kuznetsov, 1972).

Chemoprophylaxis of helminthiases is of special importance in the control of helminthiases. In this regard, the prevention of helminthiases by free feeding of phenothiazine-salt, phenothiazine-copper-sulphatesalt, and phenothiazine-molybdenum-copper-sulphate-salt mixtures in the ratios of 1:9, 10:1:89, 10:1:1:88, 
respectively, was developed in the middle of the last century (Boev \& Redko, 1947; Irgashev, 1963; Irgashev, $1963^{\mathrm{a}}$; Irgashev, $1963^{\mathrm{b}}$ ).

It should be emphasized that the introduction of chemoprophylaxis into the veterinary practice for the control of helminthiases with the use of phenothiazine-salt mixtures has led to a sharp decrease in the incidence of many helminthiases in sheep and goats, especially bunostomosis, esophagostomosis, and chabertiosis, which are almost never found at the present, the infection with dictyocaulosis, gastrointestinal strongyloidiasis, and intestinal cestodiasis has also sharply decreased.

However, due to the cessation of phenothiazine production in Yekaterinburg in the 1980 s as an environmentally harmful production, veterinary practice lost this means of preventing helminthiases, i.e. phenothiazine.

Due to the above, we developed new anthelmintic-salt mixtures using modern anthelmintic agents instead of phenothiazine - albendazole, fenbendazole, and tetramisole (Oripov \& Dzhabborov, 2000; Oripov \& Dzhabborov, 2003), as well as anthelmintic-salt mixtures with bentonite (Amonov, 2008) and mixtures, enriched with trace elements taking into account the geochemical composition of the soil in individual regions (Yuldashev, 2018). These developments are recognized as inventions and the corresponding patents are received for them (UZ№IAP03349, UZ№IAP03350, and UZ№IAP03351).

Another system of measures aimed at reducing the infestation of productive animals with helminthiases are measures aimed at increasing the body's resistance to helminthiases. In this regard, deserves attention the work on the development of methods for the use of vitamins, trace elements, and other biologically active agents that stimulate the body's natural resistance to helminthiases.

In this direction, the works of Akopian (1956), Davtian \& Akopian (1958), Akopian (1960), Oripov (1990) are of interest, in which experimental data on the positive effect of vitamin A on the increase of resistance of sheep to fasciolosis and cystocaulosis are given. It has been established that infestation of sheep with these helminthiases leads to a decrease in vitamin A content in the liver.

We also conducted research to determine the effect of micronutrients on the infestation of animals, in particular sheep, with helminthiases, as well as the effect of a natural biostimulator, gossipren, on the infestation of chickens and sheep with helminthiases and chicken productivity.

Directions, volume, and nature of our research in the above areas, analysis of the results are given below.

Analysis of the results of multi-year studies in the Republic of Uzbekistan (Badanin, 1949; Nepoklonov, 1959; Azimov, 1963; Irgashev, 1963; Sadykov, 1973; Azimov, 1974; Salimov, 1974; Oripov, 1983) shows that the main, according to the founder of helminthology in the Republic of Uzbekistan, Badanin, the "main" helminthiases in the country: in sheep and goats - fasciolosis, dicrocoeliasis, larval cestodiases (echinococcosis, coenurosis, and cysticercosis), anoplocephalatoses (monieziosis, avitellinosis, and tisaniesiosis), dictyocaulosis and gastrointestinal nematodoses (marshallagiosis, nematodirosis, ostertagiosis, etc.); in cattle - fasciolosis, dicrocoeliasis, larval cestodiases, anoplocephalatoses and gastrointestinal strongyloidiasis; in pigs - ascariasis, oesophagostomosis, and triocephalosis; in birds (chickens) under floor housing - ascariasis and heterakidosis, and in some regions - raietinosis, capillariosis, prosthogonimosis, etc. It is also established that the main helminthiases of horses in the Republic of Uzbekistan are strongylosis, strongyloidiasis, trichonematosis, and in some limited areas - anoplocephalatoses (Isaev, 2019).

For deworming of animals in the 60-70s of the last century, carbon tetrachloride, hexachlorparaxilolum, and hexichol were used, and later, in the 80-90s, dertilum (dertilum $\mathrm{O}$ for small ruminants and dertilum B for cattle) and analogs of this drug (bilevon, rafoxanide, etc.). Lugol's solution was widely used against dictyocaulosis, phenothiazine, nilverm (tetramisole), and salts of piperazine - against nematodoses, phenasalum, copper sulfate, bithionolum, dichlorophen, bunamidine, cetovex, droncit, lopatol, etc - against intestinal cestodiases. Phenothiazine, piperazine, thiabendazole and, more recently, albendazole, fenbendazole, and tetramisole have been widely used against nematodoses (Demidov \& Potemkina, 1980; Demidov, 1982).

These anthelmintic drugs were used mainly by individual deworming, i.e. were based on the administration of a certain dose of the drug to each animal individually. These methods, along with the positive qualities (accuracy of dosing based on individual indicators of the animal), have several disadvantages (requires a lot of time and labor, the possibility of injury to animals and veterinary staff) and is not always acceptable, i.e. when there is much livestock and insufficient labor force, individual deworming is difficult to carry out.

Given this situation, methods for group deworming of animals were developed - by free feeding of anthelmintic drugs in a mixture with feed (compound feed and bran), by free feeding of medicated feed pellets and briquettes (Oripov, 1978; Oripov, 1978 ; Oripov, 1978).

In addition to improving these methods, we have developed a group method of deworming sheep by administration of nilverm (tetramisole) with water ad libitum during drinking (Oripov \& Petrosian, 1974). The 
essence of this method is that the anthelmintic drug is dissolved in water intended for watering a certain group of animals (sheep and goats). To do this, it preliminarily determines the amount of water consumed by the sheep in the given conditions, which is achieved by conducting a control watering of a small group (10-15 sheep) of animals in these conditions. Then the tank is filled with water intended for watering the whole group (flock) and anthelmintic drug, in our example - nilverm (tetramisole), calculated for the whole group (flock). The anthelmintic drug is first dissolved in a small amount of water (in a bucket), which is mixed with the total volume of water (in the tank), intended for watering of all groups (flocks). Sheep are admitted to the watering hole in small groups of 50-100 animals, with the expectation that all sheep in this group have free access to the gutter where water from the tank enters.

This method has several advantages over individual deworming: it does not require much time and additional labor, eliminates injuries to animals, allows you to cover the entire livestock available on the farm, and in a short time to complete anthelmintic measures for health improvement of farms from helminthiases.

However, anthelmintic drugs with relatively high toxicity cannot be used by this method, i.e., drugs used by group methods must have a therapeutic index of at least 5 , i.e. therapeutic doses should be 5 times less than toxic.

Our method of group deworming of sheep by administration of anthelmintic drugs with water ad libitum is especially acceptable in the conditions of sheep farms located in the desert-pasture zone, where there are no open water sources and sheep go to the watering hole, which is carried out in specially equipped places. Such structures consist of deep wells, a water lift, a reservoir and a gutter for watering.

The method of group deworming of sheep with water developed by us was subjected to a commission inspection and approved by the Main Directorate of Veterinary Medicine of the Ministry of Agriculture and Food of the USSR in 1973 and accepted as an "Innovation Proposal".

Another area of the development and improvement of deworming methods is the development of methods for the use of anthelmintic drugs in feed mixtures and medicated feed pellets (Oripov, 1978; Oripov, 1978 ; Oripov, 1978). The essence of these methods is to include a therapeutic dose of anthelmintic drugs in the composition of feed (compound feed, bran) or feeding them in the form of medicated feed pellets. We have developed and implemented in the practice to control gastrointestinal and pulmonary nematodoses and anoplocephalatoses feed mixture and medicated feed pellets with nilverm (tetramisole), phenasalum for sheep, piperazine, tetramisole, and albendazole for deworming of chickens under floor housing.

The second important link in the complex of measures to control helminthiases, as is known, is measures aimed at preventing the infection of animals with helminthic pathogens in the environment - in pastures and livestock buildings.

Particularly important in this link is the infection of farm and wild animals with such very dangerous helminthiases as fasciolosis, schistosomiasis (orientobilharziasis), paramphistomatoses (paramphistomosis, liorchosis, calicophorosis, gastrotiliaxosis). The intermediate hosts for causative agents of these trematodiases (genera Fasciola, Schistosoma, and family Paramphistomatidae) are freshwater snails of the genera Lymnaea and Planorbis.

Therefore, to prevent infection of productive animals with fasciolosis, schistosomiasis (orientobilharziasis) and paramphistomatosis, it is necessary to control freshwater snails - intermediate hosts of trematodes (fascioles, schistosomes, and paramphistomes), which is achieved by draining the habitats of these snails, breeding of waterfowl (ducks, geese) - biological enemies of these snails, and the most effective and reliable way - the use of molluscicides, i.e. chemicals.

As we know, large-scale and in-depth studies have been conducted to investigate molluscicides of chemical origin (Mereminskii, 1967; Gorokhov, 1970; Zharikov, 1975). However, the developed and proposed molluscicides are usually inaccessible, and some of them are toxic to animals and not environmentally friendly (5,4-dichlorosalicylanilide, copper sulfate, etc.).

In this regard, we have developed readily available molluscicides, some of which are widely used in agriculture as a mineral fertilizer, as well as in medical practice, and the food industry. In particular, we tested various concentrations (from 1:100 to 1:1000000) of these molluscicides in experiments conducted in the laboratory (in aquariums), as well as in natural habitats of snails (springs, ditches, coastal areas of canals, rivers, and lakes, etc.).

The research results made it possible to establish that mineral fertilizers - ammonium sulfate $(\mathrm{NH})_{2} \mathrm{SO}_{4}$ and potassium chloride $(\mathrm{KCl})$ at concentrations of $0.1 \%$ and $0.2 \%$, respectively, lead to the death of snails in 24-72 hours, baking soda (sodium bicarbonate) at a concentration of 1:300-1:400, i.e. 0.3-0.4\%, also exhibits a satisfactory molluscicidal effect, and hydrogen peroxide $\left(\mathrm{H}_{2} \mathrm{O}_{2}\right)$ and potassium permanganate $\left(\mathrm{KMnSO}_{4}\right)$, at concentrations of 1:400000 and 1:400000, respectively, lead to 100\% death of snails in 24 hours. Common table salt $(\mathrm{NaCl})$ also has a certain molluscicidal effect: its concentration of 1:200-1:250 leads to the death of 
snails in 24-72 hours (Yuldashev, 2020). The molluscicides recommended by us - ammonium sulfate, baking soda, hydrogen peroxide, and potassium permanganate were accepted as "Inventions" and patents were obtained (UZ№IAP05448, UZ№IAP05449, UZ№IAP05573, and UZ№IAP05802), and developed by us "Manuals" on the application of ammonium sulfate and potassium chloride are accepted for use (State Committee of the Republic of Uzbekistan for veterinary medicine and development of animal husbandry).

Of particular importance in the prevention of helminthiases is the increase in the immunobiological defenses of the animal organism to these infections. Naturally, this is achieved by proper feeding and caring for animals, as well as by stimulating the natural defense mechanisms of the animal's body resistance to diseases through the use of immunostimulants, vitamins, enzymes, and micro-and macroelements (Daugalieva \& Oripov, 1990).

In this regard, we, together with the staff of the Institute of Chemistry of Plant Substances of the Academy of Sciences of the Republic of Uzbekistan have developed a natural biostimulator - gossipren, obtained from the leaves of the cotton plant (Gossypium hirsutum), which contains a biologically active substance from the group of polyprenols that stimulates sexual function, in particular ovulation. In addition to polyprenols, which account for $4.3 \%$ of the composition of the preparation obtained from the extract of cotton plant leaves, gossipren contains about 30 chemical substances, including tocopherols (provitamin E), phytosterols (provitamin D), carotene (vitamin A coenzyme), ascorbic acid (vitamin C) and various trace elements, enzymes, and other biologically active elements.

The use of gossipren for 3 years in poultry farms of both industrial type with cage housing systems of chickens, and private households and farms with floor housing of chickens, showed that gossipren was fed to chickens from 1-1.5 months of age with feed (feed mixture consisting bran, crushed wheat, and corn, hay flour) in an amount of $0.1 \%$ of the feed volume, led to an increase in egg production by $38-51 \%$, and the experimental pullets began to lay eggs 12-15 days earlier than their peers from the control (not receiving gossiprene) group and eggs obtained from birds of the experimental group weighed 4-5\% more than eggs obtained from birds of the control group (Oripov et al., 2016).

It was found that gossipren as an estrogenic agent, in addition to increasing the productivity of birds, has a noticeable effect on the helminthic situation in farms with floor keeping.

Thus, the average total intensity of the infection of chickens by different helminths (capillaries, raillietines, ascarides, heterakises) was 27.5 specimens in the experimental group, while in chickens of the control group that did not receive gossipren with food, an average of 151 specimens' helminths were found. Consequently, the intensity of infestation by helminths in chickens that received gossipren in the diet is about 5 times lower than in birds that did not receive this agent.

In the future, we plan to test this substance on animals, especially on multi-fetal animals - pigs, rabbits, as well as on sheep, in particular, on Karakul sheep.

\section{Conclusions and future perspectives}

It should be noted that helminths of farm animals are still often found and play a certain role in the pathology of productive animals, leading to a weakening of the body's immunobiological forces to various diseases and significantly reducing the productivity of animals.

Among the main widespread and dangerous helminthiases in cattle, sheep, and goats "except for larval cestodiases" are fascioliasis, anoplocephalatoses, in particular monieziosis and gastrointestinal strongylatoses.

Ascariasis, esophagostomosis, and trichocephalosis, and for birds (chickens) - ascariasis and heterakidosis are among the helminthiases, which are widespread and pose a danger to pigs.

Horse helminthiases, such as strongylosis, strongyloidiasis, trichonematosis, anoplocephalatoses, and in some regions, fascioliasis, oxyuriasis, etc., are quite widespread and dangerous.

The control of helminthiases should be comprehensive and cover all the details of this complex, namely: planned therapeutic and prophylactic deworming, the volumes, timing and frequency of which should be based on the results of studying the regional epizootology of helminthiases in each specific climatic and geographical zones; implementation and widespread use of methods and means of pasture prevention, including the neutralization of the external environment in relation to eggs and larvae of pathogens of geohelminthiases, as well as control of the main, intermediate, and additional hosts for pathogens of biohelminthiases; for some species of animals, for example, for sheep and goats, the use of methods and means of chemoprophylaxis, for example, feeding anthelminthic-salt mixtures; measures aimed at increasing the natural immunobiological resistance of the animal organism to various helminthiases, through the use of biological stimulants - vitamin complexes, micro-and macroelements, immunostimulants.

\section{References}


Akopian, V. D. (1960). Snizhenie "A"-vitaminnoj cennosti pecheni pri jeksprimental'nom fascioljoze i cistikauljoza ovec [Decrease in vitamin A value of the liver in experimental fascioliasis and cysticaulosis of sheep]. Bulleten n-t inform. Armyansk. NIIZHIV, 4-5, 57-60.

Akopian, V. O. (1956). Vlijanie vitamina "A" na povyshenie rezistentnosti ovec k cistokauljozu [The effect of vitamin A on increasing the resistance of sheep to cystocaulosis]. Trudy Arm.NIIZHIV, 1(9), 126-136.

Alavi, S. E., \& Shahmabadi, H. E. (2021). Anthelmintics for drug repurposing: Opportunities and challenges. Saudi Pharmaceutical Journal: SPJ, 29(5), 434. doi: 10.1016/j.jsps.2021.04.004

Amonov, O. Z. (2008). Novye antgel'mintno-solevye smesi protiv gel'mintozov v karakulevodskih hozjajstvah i tehnologija ih primenenija [New anthelmintic-salt mixtures against helminthiasis in karakul farms and the technology of their application]. (Abstract of dissertation of Candidate of Veterinary Sciences). Samarkand.

Arias, M. S., Cazapal-Monteiro, C. F., Suárez, J., Miguélez, S., Francisco, I., Arroyo, F. L., ... \& Mendoza de Gives, P. (2013). Mixed production of filamentous fungal spores for preventing soil-transmitted helminth zoonoses: a preliminary analysis. BioMed research international, 2013. doi: $10.1155 / 2013 / 567876$

Azimov, D. A. (1963). Gel'minty i gel'mintozy ovec juga Uzbekistan [Helminths and helminthoses of sheep in the south of Uzbekistan. (Abstract of dissertation of Candidate of Veterinary Sciences). Moscow.

Azimov, Sh. A. (1974). Fascioljozy i anoplocefaljatozy ovec i krupnogo rogatogo skota v Uzbekistane [Fascioliasis and anoplocephalatoses of sheep and cattle in Uzbekistan]. Tashkent: FAN UzSSR.

Badanin, N. V. (1949). Voprosy jepizootologii glavnejshih gel'mintozov karakul'skoj ovcy [Questions of epizootology of the main helminthiases of the Karakul sheep]. Trudy Uzbek Agricultural Institute, 7, 321.

Boev, S. N., \& Redko, A. S. (1947). Opyt profilaktiki diktikauljoza i trihostrongilidozov ovec metodom vol'noj dachi soli $\mathrm{s}$ primes'ju fenotiazina [Experience in the prevention of dictyocaulosis and trichostrongylidosis in sheep by the method of free giving of salt with an admixture of phenothiazine]. Veterinaria, 3.

Cabaret, J., Bouilhol, M., \& Mage, C. (2002). Managing helminths of ruminants in organic farming. Veterinary research, 33(5), 625-640. doi: 10.1051/vetres:2002043

Charlier, J., De Waele, V., Ducheyne, E., van der Voort, M., Velde, F. V., \& Claerebout, E. (2015). Decision making on helminths in cattle: diagnostics, economics and human behaviour. Irish Veterinary Journal, 69(1), 1-5.

Charlier, J., Rinaldi, L., Musella, V., Ploeger, H. W., Chartier, C., Vineer, H. R., ... \& Claerebout, E. (2020). Initial assessment of the economic burden of major parasitic helminth infections to the ruminant livestock industry in Europe. Preventive Veterinary Medicine, 182, 105103. doi: 10.1016/j.prevetmed.2020.105103

Daugalieva, E. Kh., \& Oripov, A. O. (1990). Primenenie immunostimuljatorov dlja profilaktiki gel'mintozov i povyshenija rezistentnosti zhivotnyh (metodicheskie rekomendacii) [The use of immunostimulants for the prevention of helminthiasis and increasing the resistance of animals (guidelines)]. Moscow.

Davtian, E. A., \& Akopian, V. D. (1958). Izmenenie balansa vitamina "A" u ovec pri jeksperimental'nom fascioljoze Changes in the balance of vitamin $\mathrm{A}$ in sheep with experimental fascioliasis. Izvestiya ANArmSSR, biological and agricultural sciences, 11, 17-26.

Demidov, N. V. (1982). Antgel'mintiki v veterinarii [Anthelmintics in veterinary medicine]. Moscow: Kolos.

Demidov, N. V., \& Potemkina, V. A. (1980). Spravochnik terapii i profilaktike gel'mintozov zhivotnyh. [Handbook of therapy and prevention of helminthiasis in animals]. Moscow: Kolos.

Devleesschauwer, B., Ale, A., Torgerson, P., Praet, N., Maertens de Noordhout, C., Pandey, B. D., ... \& Speybroeck, N. (2014). The burden of parasitic zoonoses in Nepal: a systematic review. PLoS neglected tropical diseases, 8(1), e2634. doi: 10.1371/journal.pntd.0002634

Dolnikov, Yu. Ya. (1956). Group deworming of pigs with fluorosilicate on trium with ascariasis. Veterinaria, $5,38-40$.

Dzhabborov, Sh. A. (2005). Development and implementation of new anthelmintic-salt mixtures against helminthiasis in sheep. (Abstract of dissertation of Candidate of Veterinary Sciences). Samarkand.

Dzhabborov, Sh. A. (2017). The effectiveness of anthelminthic measures and ways to increase it. (Abstract of dissertation of Doctor of Veterinary Sciences). Samarkand.

Foster, N., \& Elsheikha, H. M. (2012). The immune response to parasitic helminths of veterinary importance and its potential manipulation for future vaccine control strategies. Parasitology research, 110(5), 15871599. doi: 10.1007/s00436-012-2832-y 
Gorokhov, V. V. (1970). Himicheskie i biologicheskie metody bor'by s mollyuskami - promezhutochnymi hozyaevami gel'mintov [Chemical and biological methods of control of snails - intermediate hosts of helminths]. Gel'mintozy sel'skohozyajstvennyh zhivotnyh. 1969. Itogi nauki VINITI, 132-170.

Hewitson, J. P., \& Maizels, R. M. (2014). Vaccination against helminth parasite infections. Expert review of vaccines, 13(4), 473-487. doi: 10.1586/14760584.2014.893195

Idris, O. A., Wintola, O. A., \& Afolayan, A. J. (2019). Helminthiases; prevalence, transmission, host-parasite interactions, resistance to common synthetic drugs and treatment. Heliyon, 5(1), e01161. doi: 10.1016/j.heliyon.2019.e01161

Irgashev, I. Kh. (1963). Gel'mintozy melkogo rogatogo skota v uslovijah Uzbekistana [Helminthiasis of small cattle in conditions of Uzbekistan]. (Abstract of dissertation of Doctor of Veterinary Sciences). Moscow.

Irgashev, I. Kh. (1963) ${ }^{\mathrm{a}}$. Novoe v bor'be s vazhnejshimi gel'mintozami karakul'skih ovec v Uzbekistane [New in the fight against the most important helminthiases of Karakul sheep in Uzbekistan]. Trudy VNIIK, 13.

Irgashev, I. Kh. (1963) $)^{\mathrm{b}}$. Primenenie v karakulevodcheskih hozjajstvah fenotiazino-solevoj smesi s dobavleniem mednogo kuporosa i molibdena [Application in karakul farms of phenothiazine-salt mixture with the addition of copper sulfate and molybdenum], Proceedings of scientific conference, dedicated to the 90th anniversary of the Kazan veterinary institute. Kazan.

Isaev, Zh. M. (2019). Osnovnye gel'mintozy loshadej (Equus caballus), loshadi przhival'skogo (Equus prezewalski) i kulanov (Equus hemionus) [The main helminthiases of horses (Equus caballus), horses of the prezewalski (Equus prezewalski) and kulans (Equus hemionus)]. (Abstract of dissertation of $\mathrm{PhD}$ in Veterinary Sciences). Samarkand.

Kotze, A. C., Gilleard, J. S., Doyle, S. R., \& Prichard, R. K. (2020). Challenges and opportunities for the adoption of molecular diagnostics for anthelmintic resistance. International Journal for Parasitology: Drugs and Drug Resistance, 14, 264-273. doi: 10.1016/j.ijpddr.2020.11.005

Kuznetsov, M. I. (1972). Anoplocefaljatozy zhvachnyh zhivotnyh [Anoplocephalatoses of ruminants]. Moscow: Kolos.

MacDonald, A. S., Araujo, M. I., \& Pearce, E. J. (2002). Immunology of parasitic helminth infections. Infection and immunity, 70(2), 427-433. doi: 10.1128/IAI.70.2.427-433.2002

McSorley, H. J., \& Maizels, R. M. (2012). Helminth infections and host immune regulation. Clinical microbiology reviews, 25(4), 585-608. doi: 10.1128/CMR.05040-11

Mereminskii, I. A. (1967). Prognozirovanie fascioljoza i paramfistomatozov zhvachnyh zhivotnyh [Prediction of fascioliasis and paramphistomatosis in ruminants]. Veterinaria, 5, 76-78.

Morgan, E. R., Charlier, J., Hendrickx, G., Biggeri, A., Catalan, D., Samson-Himmelstjerna, V., ... \& Vercruysse, J. (2013). Global change and helminth infections in grazing ruminants in Europe: impacts, trends and sustainable solutions. Agriculture, 3(3), 484-502. doi: 10.3390/agriculture3030484

Nepoklonov, Ya. D. (1959). K voprosam jepizootologii glavnejshih gel'mintozov ovec v Kashkadar'inskoj oblasti Uzbekskoj SSR [On the issues of epizootology of the main helminthiasis of sheep in the Kashkadarya region of the Uzbek SSR]. Bolezni selskohoziaistvennyh zhyvotnykh. Sbornik nauchnyh trudov NIVI Uzbek, 13, 95-102.

Nixon, S. A., Welz, C., Woods, D. J., Costa-Junior, L., Zamanian, M., \& Martin, R. J. (2020). Where are all the anthelmintics? Challenges and opportunities on the path to new anthelmintics. International Journal for Parasitology: Drugs and Drug Resistance, 14, 8-16. doi: 10.1016/j.ijpddr.2020.07.001

Noon, J. B., \& Aroian, R. V. (2017). Recombinant subunit vaccines for soil-transmitted helminths. Parasitology, 144(14), 1845-1870. doi: 10.1017/S003118201700138X

Oripov, A. O. (1978). Deworming of sheep against strongylatosis. Veterinariia, 4, 74.

Oripov, A. O. (1978) ${ }^{\text {a }}$. Degel'mintizacija ovec protiv strongiljatozov lechebno-kormovymi granulami Deworming of sheep against strongylatosis with medicinal feed granules]. Trudy UzNIVI, 27, 88.

Oripov, A. O. (1980). Principy razrabotki i perspektivy metodov gruppovoj degel'mintizacii zhivotnyh [Principles of development and prospects of methods for group deworming of animals], Proceedings of the conference VOG USSR Academy of Sciences, 30, 78-82.

Oripov, A. O. (1983). Trihostrongilidozy ovec v Uzbekistane [Trichostrongylidosis of sheep in Uzbekistan]. (Abstract of dissertation of Doctor of Veterinary Sciences). Moscow.

Oripov, A. O. (1990). Degel'mintizacija ovec protiv strongiljatozov [Deworming of animals with medicinal feed granules and medicinal feed mixture]. Trudy UzNIVI.

Oripov, A. O., \& Dzhabborov, Sh. A. (2000). Razrabotka novyh antgel'mintno-solevyh smesej protiv gel'mintozov ovec [Development of new anthelmintic-salt mixtures against helminthiasis in sheep]. 
Y̌zbekistonda қishloқ khy̆zhalik xaivonlar kasalliklariga қarshi kurash va oldini olish tadbirlari (Ilmiy mақоllar teplami), Samarkand, 68-72.

Oripov, A. O., \& Dzhabborov, Sh. A. (2003). Novoe sredstvo dlja profilaktiki gel'mintozov ovec [A new remedy for the prevention of helminthiasis in sheep], Actual problems of animal diseases in modern conditions. proceedings of the International conference dedicated to the 60th anniversary of the Taj. NIVI, November 22, 2003. Dushanbe.

Oripov, A. O., \& Petrosian, A. S. (1974). Gruppovoj metod degel'mintizacii ovec nilvermom [Group method for deworming sheep with nilverm]. Veterinariia, 3, 64-65.

Oripov, A. O., Dzhabborov, Sh. A., \& Yuldashev, N. E. (2020). Novye metody i sredstva lecheniya i profilaktika gel'mintozov karakul'skih ovec [New methods and means of treatment and prevention of helminthiasis of Karakul sheep], Proceedings of the international scientific and practical conference "Prospects for the deepland livestock development" dedicated to the 90th anniversary of Education Research Institute of Karakul Breeding and desert ecology, Samarkand-December 10-11, 2020.

Oripov, A. O., Khalikov, S. S., Isaev, Zh. M., \& Ulashev, I. A. (2020). Effektivnost' mehanokompleksov nekotoryh antgel'mintikov protiv gel'mintozov ovec [The effectiveness of mechanocomplexes of some anthelmintics against helminthiasis in sheep], Proceedings of scientific conference in veterinary medicine and biotechnology. Samarkand.

Oripov, A. O., Salimov, B. S., Dzhabbarov, Sh. A., \& Yuldashev, N. E. (2020). Guidelines for treatment and prevention of helminthiasis in livestock. Tashkent.

Oripov, A. O., Shokhidoyatov, Kh. M., Khidirova, N. K., Mamatkulova, N. M., Akhmedov, B. N., \& Ulashev I. A. (2016). Stimulirujushhee dejstvie gossiprena na produktivnost' kur [Stimulating effect of gossiprene on the productivity of chickens], $\mathrm{V}$ International conference Distribution and control measures for especially dangerous diseases of animals and birds, August 25-26, 2016. Samarkand.

Oripov, A. O., Yuldashev, N. E., Elmurodov, B. Zh., Nasrullaev, A. O., \& Ulashev, I. A. (2016 ${ }^{\text {a }) .}$ Antgel'mintnaja aktivnost' 2-acetilaminobenzimidazola (2-ACB) i ego gidrohloridnogo soedinenija (2ACB.HCl) [Anthelmintic activity of 2-acetylaminobenzimidazole (2-ACB) and its hydrochloride compound (2-ACB $\mathrm{HCl})$ ], V International conference Distribution and control measures for especially dangerous diseases of animals and birds, August 25-26, 2016. Samarkand.

Oripov, A. O., Yuldashev, N. E., Elmurodov, B. Zh., Nasrullaev, A. O., \& Ulashev, I. A. (2016 ${ }^{\text {b). }}$ Fasciolocidnaja aktivnost' digidrohinozolin-4 [Fasciolocidal activity of dihydroquinosolin-4], V International conference Distribution and control measures for especially dangerous diseases of animals and birds, August 25-26, 2016. Samarkand.

Reda, A. A. (2018). Probiotics for the control of helminth zoonosis. Journal of veterinary medicine, 2018, 4178986. doi: $10.1155 / 2018 / 4178986$

Rehman, A., \& Abidi, S.M.A. (2021). Livestock health: current status of helminth infections and their control for sustainable development, In R. C. Sobti (Ed.), Advances in Animal Experimentation and Modeling (pp. 365-378), United Kingdom: Academic Press. doi: 10.1016/B978-0-323-90583-1.00029-5.

Robinson, M. W., \& Dalton, J. P. (2009). Zoonotic helminth infections with particular emphasis on fasciolosis and other trematodiases. Philosophical Transactions of the Royal Society B: Biological Sciences, 364(1530), 2763-2776. doi: 10.1098/rstb.2009.0089

Sadykov, V. M. (1973). Jehinokkoz i bor'ba s nim [Echinoccosis and the fight against it]. Moscow.

Salimov, B. S. (1974). Jeksperimental'nye issledovanija po dikrocelioz zhivotnyh, jepizootologija zabolevanija i mery bor'by s nim v Uzbekistane [Experimental studies on animal dicroceliosis, epizootology of the disease and measures to combat it in Uzbekistan]. (Abstract of dissertation of Doctor of Veterinary Sciences). Moscow.

Tinkler, S. H. (2020). Preventive chemotherapy and anthelmintic resistance of soil-transmitted helminths-Can we learn nothing from veterinary medicine? One Health, 9, 100106. doi: 10.1016/j.onehlt.2019.100106

Tsotetsi, A. M., Njiro, S., Katsande, T. C., Moyo, G., \& Mpofu, J. (2013). Prevalence of gastrointestinal helminths and anthelmintic resistance on small-scale farms in Gauteng Province, South Africa. Tropical animal health and production, 45(3), 751-761. doi: 10.1007/s11250-012-0285-z

Waller, P. J. (2006). From discovery to development: current industry perspectives for the development of novel methods of helminth control in livestock. Veterinary parasitology, 139(1-3), 1-14. doi: 10.1016/j.vetpar.2006.02.036

Yuldashev, N. (2020). Anthelmintic-salt mixtures - an effective means in prevention of helminthiases in sheep. Ukrainian Journal of Veterinary Sciences, 11(4), 4-12. doi: 10.31548/ujvs2020.04.001 
Yuldashev, N. (2020). New molluscicides in control of freshwater snails - intermediate hosts for causative agents of fascioliasis, paramphistomatosis and orientobilharziasis. Scientific reports of NULES of Ukraine, 0(6(88)). doi: 10.31548/dopovidi2020.06.022

Yuldashev, N. E. (2018). Sovremennye metody i sredstva bor'by s gel'mintozami [Modern methods and means of the control of helminthiases]. (Abstract of dissertation of Doctor of Veterinary Sciences). Samarkand.

Yuldashev, N. E., \& Oripov, A. O. (2016). Poisk novyh molljuskocidov protiv presnovodnyh molljuskov [Search for new molluscicides against freshwater snails], V International conference Distribution and control measures for especially dangerous diseases of animals and birds, August 25-26, 2016. Samarkand.

Zharikov, I. S. (1975). Profilaktiki gel'mintozov krupnogo rogatogo skota v promyshlennyh zhivotnovodcheskih kompleksah Belorusskoj SSR [Prevention of helminthiasis in cattle in industrial livestock complexes of the Byelorussian SSR]. Problemy komplektovanija ferm zhivotnymi i veterinarnaja ohrana, 190-196.

\section{СУЧАСНА СТРАТЕГІЯ, НОВІ МЕТОДИ І ЗАСОБИ БОРОТЬБИ 3 ГЕЛЬМІНТОЗАМИ В УЗБЕКИСТАНІ}

\section{А. О. Оріпов, Н. Е. Юлдашев}

Анотація. Сучасна стратегія боротьби проти основних, широко розповсюджених гельмінтозів сільськогосподарських тварин передбачає проведення комплексу протигельмінтозних заходів, що включає: планові лікувально-профілактичні дегельмінтизачії, які трунтуються на даних вивчення епізоотології гельмінтозів у кожній конкретній клімато-географічній зоні; здійснення заходів пасовищної профілактики геогельмінтозів і боротьбу з основними, проміжними й додатковими господарями збудників біогельмінтозів, у тому числі й зоонозних гельмінтозів (ехінококозу, ценурозу й цистицеркозів); здійсненні заходів хіміопрофілактики гельмінтозів у деяких галузях тваринництва, наприклад, у вівчарстві; за допомогою застосування антигельмінтно-сольових сумішей; використання коштів, що підвищують імунобіологічні захисні властивості організму тварин до гельмінтозів та інших захворювань за допомогою широкого застосування вітамінів, мікро- та макроелементів та інших біологічних стимуляторів.

Ключові слова: гельмінти, гельмінтози, дегельмінтизаџія, молюскоциди, антигельмінтики, антигельмінтно-сольові суміші, імуностимулятори 